\title{
Squamous Cell Carcinoma, Clear Cell Type
}

National Cancer Institute

\section{Source}

National Cancer Institute. Squamous Cell Carcinoma, Clear Cell Type. NCI Thesaurus.

Code C65180.

A squamous cell carcinoma characterized by the presence of malignant cells with clear cytoplasm. 